\title{
A Critical Appraisal of Growth Hormone Therapy in Growth Hormone Deficiency and Turner Syndrome Patients in Turkey
}

\author{
Zehra Yavaş Abalı1, Feyza Darendeliler¹, Olcay Neyzi2 \\ 1/stanbul University Istanbul Faculty of Medicine, Department of Pediatrics, Division of Pediatric Endocrinology, Istanbul, Turkey \\ 2Emeritus Professor
}

\section{ABSTRACT}

Early detection of abnormal growth, identification of the underlying cause, and appropriate treatment of the medical condition is an important issue for children with short stature. Growth hormone (GH) therapy is widely used in GH-deficient children and also in non-GH-deficient short stature cases who have findings conforming to certain indications. Efficacy of GH therapy has been shown in a multitude of shortand long-term studies. Age at onset of $\mathrm{GH}$ therapy is the most important factor for a successful treatment outcome. Optimal dosing is also essential. The aim of this review was to focus on challenges in the early diagnosis and appropriate management of short stature due to GH deficiency (GHD) and Turner syndrome. These are the most frequent two indications for GH therapy in Turkey approved by the Ministry of Health for coverage by the national insurance system.

Keywords: Growth hormone, growth hormone deficiency, Turner syndrome

Conflict of interest: None declared

Received: 01.04 .2016

Accepted: 25.06 .2016

\section{Introduction}

Today, Turkey's population exceeds 78 million with children and adolescents constituting nearly one third of the total population (1). Being the best indicator of general health and well-being, appropriate monitoring of growth status and thus early identification of abnormal growth seems fundamental to health care in such a youthful population given the likelihood of management of underlying medical conditions, optimizing attainment of good health and normal adult height (2).

Accurate assessment and monitoring of growth in children on the basis of length or height according to age, weight, body mass index (BMI), and height velocity $(\mathrm{HV})$ with respect to reference

\section{Address for Correspondence}

Feyza Darendeliler MD, Istanbul University Istanbul Faculty of Medicine, Department of Pediatrics, Division of Pediatric Endocrinology, Istanbul, Turkey Phone: +90 2124142000 E-mail: feyzad@istanbul.edu.tr

OJournal of Clinical Research in Pediatric Endocrinology, Published by Galenos Publishing. 
Yavaș Abalı Z et al.

Growth Hormone Therapy in Growth Hormone Deficiency and Turner Syndrome in Turkey

populations is of critical importance for early identification and proper evaluation of remediable conditions associated with a reduced growth rate and/or short stature. Early initiation of treatment in children with these conditions would possibly enable them to achieve their potential to reach an adult height within the normal population range $(2,3)$.

The further below -2.0 standard deviations [SD] $(2.5$ percentile) an individual's growth falls, the more likely it is that there is an underlying pathological condition associated with short stature. The possibility to reach the genetically determined height potential also becomes more limited in such individuals $(2,4)$.

According to data from the Turkish Demographic and Health Survey, an improvement was noted in the nutritional status of children over the years with a dramatic decrease in the frequency of undernutrition- and malnutrition-related growth failure (5). Additionally, the recent report of the Turkey Childhood Obesity Surveillance Initiative in 2013 stated that the frequency of children (aged 7-8 years) with a height standard deviation score (SDS) below -3 SD is $0.1 \%$ and that of those with a height below -2 SD is $2.3 \%(6)$. Nonetheless, despite this decline in the frequency of short children over the years, there are still several underlying causes of short stature other than those related to nutrition that need to be evaluated by pediatric endocrinologists.

Pituitary-derived human $\mathrm{GH}$ was first used as replacement therapy in a child with hypopituitarism (7). In subsequent years, with the development of the recombinant human $\mathrm{GH}$ $(\mathrm{rhGH})$ and its introduction to clinical use, there has been a marked increase in the scope of $\mathrm{GH}$ treatment (8). Indications for $\mathrm{GH}$ therapy extended from replacement therapy in $\mathrm{GH}$ deficiency (GHD) to many diseases in which short stature is not secondary to GHD (9). Among several indications of $\mathrm{GH}$ treatment $(10,11), \mathrm{GHD}$ and Turner syndrome (TS) are the two most frequent conditions approved for $\mathrm{GH}$ treatment by the Turkish Ministry of Health. In this context, it must also be noted that under the Turkish national health system, all individuals are covered for their health expenditures, including $\mathrm{GH}$ treatment.

In Turkey, there are 73 pediatric endocrinology centers with a total number of 200 endocrinologists (according to 2015 data) (12). The Turkish Pediatric Endocrinology and Diabetes Society (TPEDS) is an active society that holds regular annual scientific meetings and that also organizes periodic educational conferences on growth disorders among other endocrine issues. TPEDS also has many publications including consensus reports and expert reports relating to the diagnosis and treatment of $\mathrm{GH}$ deficiency $(13,14,15,16,17,18,19,20)$. Although there are many studies on growth disorders, early diagnosis of the underlying cause of short stature and especially the diagnosis of conditions that may benefit from $\mathrm{GH}$ treatment is still a challenge.
The aim of this review is to focus on the early diagnosis and appropriate management of GHD and TS patients, with emphasis on optimum GH treatment, compliance to therapy, and transition to adult healthcare.

\section{Growth Hormone Therapy in Children with Growth Hormone Deficiency}

The diagnosis of GHD is usually based on the combination of auxological findings and poor growth velocity, confirmed by a low insulin-like growth factor-1 (IGF-1) concentration and the results of $\mathrm{GH}$ provocative testing using arginine, clonidine, glucagon, insulin, or L-dopa, with a peak GH cut-off set at 10 $\mu \mathrm{g} / \mathrm{L}$ in at least two tests (21). In recent reports, it has been recommended that a cut-off peak level of $7 \mu \mathrm{g} / \mathrm{L}$ would be appropriate using the recent monoclonal $\mathrm{GH}$ antibodies (22).

Age at initiation of $\mathrm{GH}$ treatment has been shown to negatively correlate to response to therapy emphasizing the need of early diagnosis and treatment (23). In a multicenter study using the Turkish data in the KIGS database, 1008 cases with GHD were evaluated demographically and by treatment results of the first year. It was concluded that the diagnosis of GHD was late in these cases. Mean age (minimum-maximum) at onset of therapy was 11.3 (5.4-15.1) years in idiopathic GHD cases. Mean height SDS was -3.1 $(-5.2$ to -1.9$)$ in these patients (24). Mean GH dose was 28 (21-34) $\mu \mathrm{g} / \mathrm{kg} / \mathrm{d}$. The response expressed as delta height SDS was $0.6 / 1$ year and $1.1 / 3$ years of therapy which was within expected limits but at the lower end (25). To standardize the diagnosis and treatment of GHD in Turkey, TPEDS is working on new consensus guidelines for diagnostic procedures and treatment of Turkish children with $\operatorname{GHD}(26,27)$.

Several prevailing guidelines for the diagnosis and treatment of GHD in children have been published $(23,28,29,30,31,32)$. However, differences in diagnostic procedures and treatment strategies among countries and even among centers in the same country continue to exist $(33,34)$. The European Society of Pediatric Endocrinology (ESPE) recommends 25-35 $\mathrm{\mu g} / \mathrm{kg} / \mathrm{d}$ as starting doses of $\mathrm{rhGH}$ in $\mathrm{GHD}$, while the dose recommended by the American Society of Pediatric Endocrinology is $43 \mu \mathrm{g} / \mathrm{kg} / \mathrm{d}$ (32). In a recent study on current practice in diagnosis and treatment of GHD in childhood in Turkey, the most frequently used starting dose of $\mathrm{rhGH}$ was reported to be $25-30 \mu \mathrm{g} / \mathrm{kg} / \mathrm{d}$ in prepubertal children and $30-35 \mu \mathrm{g} / \mathrm{kg} / \mathrm{d}$ in pubertal children, consistent with ESPE recommendations (35).

In this survey, rhGH dose adjustment was primarily based on growth velocity as recommended by consensus publications with monitoring response and change in $\mathrm{HV}$ every 3-6 months. Cessation of rhGH therapy was primarily done according to $\mathrm{HV}$ and bone age advancement (35). There are different practices in European countries as well despite the published guidelines. In an audit from European 
Yavaş Abalı Z et al.

Growth Hormone Therapy in Growth Hormone Deficiency and Turner Syndrome in Turkey

countries, the range of starting doses of $\mathrm{GH}$ in $\mathrm{GHD}$ patients was broad $(11-50 \mu \mathrm{g} / \mathrm{kg} / \mathrm{d})$ and approximately $60 \%$ of the units from EU cenetrs preferred the dose of $30 \mu \mathrm{g} / \mathrm{kg} / \mathrm{d}(36)$. Recent multicenter Italian study reported that median dose of $\mathrm{GH}$ was $33 \mu \mathrm{g} / \mathrm{kg} / \mathrm{d}$ in GHD patients (37).

\section{Growth Hormone Therapy in Children with Turner Syndrome}

TS, the most common sex chromosome abnormality in females with an estimated prevalence of $1 / 2500$ occurs as a result of partial or complete absence of one $X$ chromosome, leading to a combination of characteristic phenotypic features including short stature (3).

The average adult height deficit in untreated women with TS is $20-21 \mathrm{~cm}$ compared to normal adults, with an average height of $147 \mathrm{~cm}$ (38). The therapeutical GH doses exceeding the physiological dose have been shown to improve growth velocity (39). However, the effect of $\mathrm{GH}$ therapy on the final height is substantially variable depending on several clinical and genetic factors such as polymorphisms related with $\mathrm{GH}$ receptor and/or IGFBP3 gene, young age, and bone age delay at the start of $\mathrm{GH}$ treatment. $\mathrm{GH}$ dose, duration of $\mathrm{GH}$ treatment, maternal $X$ chromosome origin, target height, and good firstyear height response to $\mathrm{GH}$ treatment, use of oxandralone and weekly number of injections have also been shown to affect treatment results $(40,41,42)$. Since the growth response is known to decrease over the years of $\mathrm{GH}$ treatment, not only the good first-year response to GH therapy but also maintenance of the good response has been considered necessary to be able to achieve final height. Hence, increments in $\mathrm{GH}$ dose in patients at risk of poor $\mathrm{GH}$ response have been considered to be effective in terms of cost and safety via generating better short- and long-term growth response $(40,43)$.

Prompt initiation of $\mathrm{GH}$ treatment has been recommended in TS patients as soon as growth failure is demonstrated, even in infancy. Initiation of therapy at a young age, optimally while the child is still within normal length/height values for age, has been reported to improve the outcome, to decrease overall cost, and also to yield higher psychosocial benefits such as being closer to peers in height throughout life. With early treatment, puberty can also be more likely to be initiated at a normal age and $\mathrm{GH}$ therapy is likely to be terminated earlier (41).

Hence, early initiation of $\mathrm{GH}$ treatment (at a dose of 50 $\mu \mathrm{g} / \mathrm{kg} / \mathrm{d}$ ) and induction of puberty at a normal physiological age were emphasized as important to achieve a taller adult stature (3). Younger age and tall height at GH therapy onset, tall parental heights, better first-year responsiveness to $\mathrm{GH}$, long duration of therapy, and a high $\mathrm{GH}$ dose were reported amongst the factors predictive of taller adult height (44).

Data from a past study in Turkish TS patients revealed final height of non-GH treated TS cases to be $141.6 \mathrm{~cm}$, which was $18.4 \mathrm{~cm}$ lower than average final height of women without TS (38).
A national survey with a multicenter design conducted in 2003 revealed that only $32 \%$ out of 367 TS patients received $\mathrm{GH}$ therapy. Of these, regular $\mathrm{GH}$ therapy was given to $72 \%$. Advanced chronological age and/or bone age (35\%) and lack of insurance benefits $(61 \%)$ were the two most important factors in not initiating $\mathrm{GH}$ therapy (20).

Evaluation of the data of 70 TS patients registered from 11 centers in Turkey in the KIGS database who received GH in a dose of $33(0.23 / 46) \mu \mathrm{g} / \mathrm{kg} / \mathrm{d}$ subcutaneously, 6-7 times per week, with onset of therapy at age $12.5(7.1 / 15.6)$ years revealed a non-significant increase in $\mathrm{HV}$ [6.3 (4.3/8.5) cm/year in the first year and $5.9(3.6 / 8.7) \mathrm{cm} /$ year in the second year]. Height SDS improved to $-3.4(-4.6 /-2.2)$ in the first year and to $-2.7(-4.2 /-1.6)$ in the $2^{\text {nd }}$ year of therapy in the longitudinally followed TS patients (45). Thus, in Turkish children, there was a delay in both age at diagnosis of TS and age of onset of $\mathrm{GH}$ therapy as compared to other reports. The dose of $\mathrm{GH}$ used and the response were also lower (44). In an Italian multicenter study, median GH dose used for TS was $43 \mu \mathrm{g} / \mathrm{kg} / \mathrm{d}$ (37). In another recent multicenter study, age at onset of $\mathrm{GH}$ therapy was $9.4 \pm 2.6$ years, the dose of $\mathrm{GH}$ used was $50 \mu \mathrm{g} / \mathrm{kg} / \mathrm{d}$, and delta height SDS over 1 year was 0.4 SD (46). In a very recent study from Turkey, evaluation of 842 patients with TS from 35 centers revealed that mean age at diagnosis of TS was 10.5 \pm 4.8 years with initiation of $\mathrm{rhGH}$ therapy shortly after diagnosis, at $10.7 \pm 3.5$ years (47). The number of $\mathrm{GH}$ treated patients was 615 in this cohort. The age at initiation of $\mathrm{GH}$ therapy in girls with TS improved in Turkey by years. We think that it is related to increased number of pediatric endocrinologist in Turkey and more frequent referral of patients with short stature to pediatric endocrinologists. The other important factor is continuous post-graduate education to pediatricians, family doctors, and pediatric endocrinologists. Last but not the least, almost all children under 18 years have insurance.

Evaluation of $\mathrm{GH}$ treatment response in TS patients either according to prediction models or HV target charts $(48,49)$ will enable the clinician to evaluate the confounding factors and use optimum dose adjustment and also to be able to provide realistic information to the child and the parents.

\section{Adherence to Growth Hormone Therapy}

Long-term GH replacement therapy in GHD, starting at the time of diagnosis, typically from childhood throughout adolescence and into adulthood is recommended by the GH Research Society and the European Society of Pediatric Endocrinology $(23,50)$. Accordingly, as in non-life-threatening chronic conditions, problems with adherence to GH therapy may be exacerbated due to long treatment duration along with factors specific to GH therapy such as the need for subcutaneous injections on a daily basis, inadequate training in device technique, as well as lack of immediate therapeutic benefits $(50,51,52,53)$. 
Yavaș Abalı Z et al.

Growth Hormone Therapy in Growth Hormone Deficiency and Turner Syndrome in Turkey

Data suggest that poor adherence is frequent among patients receiving $\mathrm{GH}$ therapy, despite the fact that continuous, long-term adherence is essential to achieve optimal therapeutic results with $\mathrm{GH}(54,55)$. Given the association of injection frequency with growth response, lower adherence to $\mathrm{GH}$ therapy has been associated with significantly reduced height velocities $(53,55)$.

Data of $217 \mathrm{GH}$-naïve patients from 6 pediatric endocrinology clinics in Turkey revealed a decrement in adherence to $\mathrm{GH}$ therapy during a 12-month period (Figure 1). Excellent adherence ratio in the first 3 months was $88 \%$, however it was $78 \%$ at the end of the first year. The poor adherence ratio was increased $3 \%$ to $7.5 \%$ in one-year period of treatment. In this study, patients with excellent and good adherence had better response to $\mathrm{GH}$ therapy. Also, growth velocity SDS was shown to correlate negatively with number of missed injections and positively with delta IGF-1 levels (51).

Hence, in patients who do not adhere to the prescribed $\mathrm{GH}$ therapy, there is a risk that they will not achieve the physical and psychological benefits of treatment and it is therefore important to consider non-adherence to contribute to variability in response to $\mathrm{GH}$ therapy and to be a possible cause in all cases of treatment failure.

In conclusion, we believe it is fair to state that the continuous education programs for medical doctors and other health workers conducted by the TPEDS, in addition to the several initiative efforts of our pediatric endocrinologist colleagues in Turkey towards improving the state regulations, have contributed much to the improvement and expansion of $\mathrm{GH}$ treatment in GHD and TS in Turkish children. However, we are still faced with challenges and barriers against early diagnosis

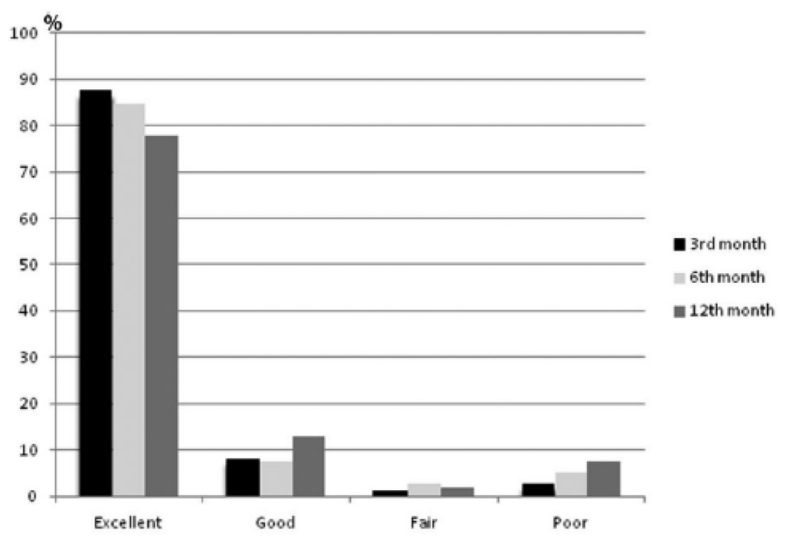

Figure 1. Percentage of adherence and decrement in adherence in the first year of growth hormone therapy (51)

Adherence segments based on percentage of doses omitted at each evaluation period: Excellent: $0 \%$, good: $5 \%$, fair: 5 to $10 \%$, and poor: $>10 \%$

Adapted from Aydın BK, Aycan Z, Sıklar Z, Berberoğlu M, Ocal G, Cetinkaya S, Baș VN, Kendirci HN, Cetinkaya E, Darcan S, Gökșen D, Evliyaoğlu O, Sükür M, Baş F, Darendeliler F. Adherence to growth hormone therapy: results of a multicenter study. Endocr Pract 2014;20:46-51. and optimal dosing in Turkey. Continuous growth monitoring and correct evaluation of short stature or poor growth and referral to secondary or tertiary centers is mandatory for early diagnosis of the underlying etiology of short stature. Once indication of $\mathrm{GH}$ therapy is made, correct dosing and correct interpretation of growth velocity is important for optimum outcome.

\section{Acknowledgments}

The authors would like to thank to Prof. Şule Oktay, MD, PhD and Çağla Ayhan, MD from KAPPA Consultancy Training and Research Ltd. for their medical writing services funded by Novo-Nordisk Turkey.

\section{Ethics}

Peer-review: Internally peer-reviewed.

\section{Authorship Contributions}

Concept: Feyza Darendeliler, Design: Feyza Darendeliler, Data Collection or Processing: Zehra Yavaş Abalı, Feyza Darendeliler, Olcay Neyzi, Analysis or Interpretation: Feyza Darendeliler, Olcay Neyzi, Literature Search: Zehra Yavaş Abalı, Feyza Darendeliler, Olcay Neyzi, Writing: Zehra Yavaş Abalı, Feyza Darendeliler, Olcay Neyzi.

\section{References}

1. Turkish Statistical Institute Population and Migration Statistics Group. Address based population registration system results 2015. Available at: http://www.turkstat.gov.tr Accessed March 2016.

2. Haymond M, Kappelgaard AM, Czernichow P, Biller BM, Takano K, Kiess W; Global Advisory Panel Meeting on the Effects of Growth Hormone. Early recognition of growth abnormalities permitting early intervention. Acta Paediatr 2013;102:787-796. Epub 2013 May 13

3. Rogol $A D$, Hayden GF. Etiologies and early diagnosis of short stature and growth failure in children and adolescents. J Pediatr 2014;164(Suppl 5):1-14.

4. De Onis M, Blössner M. WHO Global Database on Child Growth and Malnutrition. World Health Organization. Geneva, 1997. Available at: http://libdoc.who.int/hq/1997/NHO_NUT_97.4.pdf. Accessed May 2015.

5. Hacettepe University Institute of Population Studies. Turkey Demographic and Health Survey 2008. Ankara, 2009. Available at: http://www.hips.hacettepe.edu.tr/eng/tdhs08/TDHS-2008_Main_ Report.pdf Accessed Dec 2015

6. Republic of Turkey Ministry of Health Turkish Public Health Institution, Department of Obesity, Diabetes and Metabolic Diseases Turkey Childhood (Ages 7-8) Obesity Surveillance Initiative (COSI-TUR) 2013. Ankara, 2014. Available at: http://www.halksagligiens.hacettepe.edu. tr/english/cosi_ing-2014.pdf Accessed Dec 2015

7. Raben MS. Treatment of a pituitary dwarf with human growth hormone. J Clin Endocrinol Metab 1958;18:901-903.

8. Darendeliler F. Safety of growth hormone treatment. J Clin Res Ped Endo 2009;1(Suppl 1):36-43.

9. Rosenbloom AL. Pediatric endo-cosmetology and the evolution of growth diagnosis and treatment. J Pediatr 2011;158:187-193. Epub 2010 Dec 18 
10. Backeljauw PF, Dattani MT, Cohen P, Rosenfeld RG. Disorders of growth hormone/insulin-like growth factor secretion and action. In: Sperling MA (ed). Pediatric Endocrinology. 4th edition. Philadelphia, Elsevier Saunders, 2014:292-404.

11. Guyda HJ. Four decades of growth hormone therapy for short children: what have we achieved? J Clin Endocrinol Metab 1999;84:4307-4316.

12. Turkish Pediatric Endocrinology and Diabetes Society webpage. Available at: www.cocukendokrindiyabet.org. Accessed Dec 2014.

13. Ulusal Pediatrik Endokrinoloji Derneği. Çocukluk ve ergenlik döneminde büyüme hormonu eksikliği tanı ve tedavi uzlaşı raporu (Bölüm 1): Büyüme hormonu eksikliği tanısı. Çocuk Dergisi 2006;6:1116. (in Turkish)

14. Bereket A, Özkan B, Kurtoğlu S. Turner sendromunda tanı ve tedavi: Ulusal Pediatrik Endokrinoloji Derneği olarak katkı. Çocuk Dergisi 2005:5:81-86. (in Turkish)

15. Berberoğlu M, Darendeliler F, Darcan $S$, et al. Çocukluktan erişkin döneme geçişte büyüme hormonu eksikliğinin değerlendirilmesi. Endokrinolojide Yönelişler 2004;13:133-136. (in Turkish)

16. Darendeliler F, Darcan $S$, Ulusal Pediatrik Endokrinoloji Derneği. Çocukluk ve ergenlik döneminde büyüme hormonu eksikliği tanı ve tedavisi uzlaşı raporu (Bölüm 2): Büyüme hormonu eksikliği tedavisi. Çocuk Dergisi 2006;6:89-94. (in Turkish)

17. Minutes of the Turkish Pediatric Endocrinology and Diabetes Society and Turkish Adult Endocrinology and Metabolism Society. Workshop on Transition in Endocrine Patients. Coordinator: Kurtoğlu S, 9-10 Sept 2011, Kayseri. (in Turkish)

18. Bereket A, Büyükgebiz A, Özkan B, Darendeliler F, Berberoğlu M, Tarım Ö, Kurtoğlu S. Gestasyon yaşına göre küçük doğan bebeklerde (SGA) tanı ve tedavi önerileri: Novo Nordisk Danışma Kurulu. Endokrinde Yönelişler 2007;16:193-196. (in Turkish)

19. Darcan Ş, Arslanoğlu I, Berberoğlu $M$, Bundak R, Yüksel B, Bideci $A$, Darendeliler F. Boy kısalığı tanım ve sınıflandırma: Aynı ölçütlerle mi boy kısalı̆ı diyoruz? Ege Pediatri Bülteni 2006;13:127-133. (in Turkish)

20. Darendeliler F. Türkiyede TS'da Büyüme hormonu tedavisi ve güncel durum. Çocukluktan erişkinliğe Turner sendromu. Pediyatrik Endokrinoloji ve Oksoloji Derneği Sempozyumu II. 7 Haziran 2003, Istanbul. (in Turkish)

21. Sizonenko $P C$, Clayton $P E$, Cohen $P$, Hintz RL, Tanaka T, Laron Z. Diagnosis and management of growth hormone deficiency in childhood and adolescence. Part 1: diagnosis of growth hormone deficiency. Growth Horm IGF Res 2001;11:137-165.

22. Ho KK; 2007 GH Deficiency Consensus Workshop Participants. Consensus guidelines for the diagnosis and treatment of adults with GH deficiency II: a statement of the GH Research Society in association with the European Society for Pediatric Endocrinology, Lawson Wilkins Society, European Society of Endocrinology, Japan Endocrine Society, and Endocrine Society of Australia. Eur J Endocrinol 2007;157:695-700.

23. Growth Hormone Research Society. Consensus guidelines for the diagnosis and treatment of growth hormone $(\mathrm{GH})$ deficiency in childhood and adolescence: summary statement of the GH Research Society. J Clin Endocrinol Metab 2000;85:3990-3993.

24. Darendeliler F, Berberoğlu M, Öcal G. Büyüme hormonu eksikliği etiyolojisi, demografik veriler ve tedavi sonuçlarının değerlendirilmesi: Türkiye verileri. KIGS analiz sonuçları. Çocuk Dergisi 2004;4:141-148. (in Turkish)

25. Bang P, Ahmed SF, Argente J, Backeljauw P, Bettendorf M, Bona G, Coutant R, Rosenfeld RG, Walenkamp MJ, Savage MO. Identification and management of poor response to growth-promoting therapy in children with short stature. Clin Endocrinol (Oxf) 2012;77:169-181.

26. Darcan Ş, Poyrazoğlu Ş, Çetinkaya S. Büyüme hormonu eksikliğinin tanısı. Içinde: Saka N, Akcay T (eds). Çocuk Endokrinolojisinde Uzlaşı. 1st edition. Nobel Tip Kitabevleri, 2014:3-9.
27. Darendeliler F, Andıran N, Evliyaoğlu O, Uçkun Kitapçı A. Büyüme hormonu eksikliğinin tedavisi. Içinde: Saka N, Akcay T (eds). Çocuk Endokrinolojisinde Uzlaşı. 1st edition. Nobel Tıp Kitabevleri, 2015:11-24.

28. No authors listed. Guidelines for the use of growth hormone in children with short stature. A report by the Drug and Therapeutics Committee of the Lawson Wilkins Pediatric Endocrine Society. J Pediatr 1995;127:857-867.

29. Darendeliler F. Büyüme Hormonu tedavisinde kanıta dayalı uygulamalar. Çocuk Dergisi 2009;9:158-166. (in Turkish)

30. Saggese G, Ranke MB, Saenger P, Rosenfeld RG, Tanaka T, Chaussain $\mathrm{JL}$, Savage MO. Diagnosis and treatment of growth hormone deficiency in children and adolescents: towards a consensus. Ten years after the Availability of Recombinant Human Growth Hormone Workshop held in Pisa, Italy, 27-28 March 1998. Horm Res 1998;50:320-340.

31. Wilson $T A$, Rose $S R$, Cohen $P$, Rogol $A D$, Backeljauw $P$, Brown R, Hardin DS, Kemp SF, Lawson M, Radovick S, Rosenthal SM, Silverman L, Speiser P; Lawson Wilkins Pediatric Endocrinology Society Drug and Therapeutics Committee. Update of guidelines for the use of growth hormone in children: the Lawson Wilkins Pediatric Endocrinology Society Drug and Therapeutics Committee. J Pediatr 2003;143:415-421.

32. Cook DM, Rose SR. A review of guidelines for use of growth hormone in pediatric and transition patients. Pituitary 2012;15:301 310.

33. Juul A, Bernasconi S, Clayton PE, Kiess W, DeMuinck-Keizer Schrama S; Drugs and Therapeutics Committee of the European Society for Paediatric Endocrinology (ESPE). European audit of current practice in diagnosis and treatment of childhood growth hormone deficiency. Horm Res 2002;58:233-241.

34. Wyatt DT, Mark D, Slyper A. Survey of growth hormone treatment practices by 251 pediatric endocrinologists. J Clin Endocrinol Metab 1995:80:3292-3297.

35. Poyrazoğlu Ş, Akçay T, Arslanoğlu I, Atabek ME, Atay Z, Berberoğlu M, Bereket A, Bideci A, Bircan I, Böber E, Can Ş, Cesur Y, Darcan Ş, Demir K, Dündar B, Ersoy B, Esen I, Güven A, Kara C, Keskin M, Kurtoğlu S, Memioğlu N, Özbek MN, Özgen T, Sarı E, Şılar Z, Şimșek E, Turan S, Yeşilkaya E, Yüksel B, Darendeliler F. Current practice in diagnosis and treatment of growth hormone deficiency in childhood: A survey from Turkey. J Clin Res Pediatr Endocrinol 2015;7:37-44.

36. Juul A, Bernasconi S, Clayton PE, Kiess W, DeMuinck-Keizer Schrama S; Drugs and Therapeutics Committee of the European Society for Paediatric Endocrinology (ESPE). European audit of current practice in diagnosis and treatment of childhood growth hormonedeficiency. Horm Res 2002;58:233-241.

37. Cappa M, lughetti L, Loche S, Maghnie M, Vottero A; GeNeSIS National Board on behalf of theGeNeSIS Italian Investigators. Efficacy and safety of growth hormone treatment in children with short stature: the Italian cohort of the GeNeSIS clinical study. J Endocrinol Invest 2016;39:667-677. Epub 2015 Dec 28

38. Bereket A, Turan $S$, Elçioğlu N, Hacihanefioğlu S, Memioğlu N, Baş F, Bundak R, Darendeliler F, Günöz H, Saka N, Ercan O, Arslanoğlu I, Işgüven P, Yildiz M, Can S, Ozerkan E, Coker M, Darcan S, Ozkan B, Orbak Z, Oztaş S, Palandüz S, Sezgin I, Atabek E, Erkul I, Erdoğan G. Adult height in Turkish patients with Turner syndrome without growth hormone treatment. Turk J Pediatr 2008;50:415-417.

39. Van den Broeck J, Massa GG, Attanasio A, Matranga A, Chaussain JL, Price DA, Aarskog D, Wit JM. Final height after long-term growth hormone treatment in Turner syndrome. European Study Group. J Pediatr 1995;127:729-735.

40. Ranke MB, Lindberg A, Ferrández Longás A, Darendeliler F, AlbertssonWikland K, Dunger D, Cutfield WS, Tauber M, Wilton P, Wollmann HA, 
Yavaș Abalı Z et al.

Growth Hormone Therapy in Growth Hormone Deficiency and Turner Syndrome in Turkey

Reiter EO; KIGS International Board. Major determinants of height development in Turner syndrome (TS) patients treated with $\mathrm{GH}$ : analysis of 987 patients from KIGS. Pediatr Res 2007;61:105-110.

41. Davenport ML. Growth hormone therapy in Turner syndrome. Pediatr Endocrinol Rev. 2012;9(Suppl 2):723-724.

42. Özgen IT, Adal E, Ünüvar T, Önal H, Sarıkaya AS, Akın L. Response to growth hormone therapy in patients with Turner syndrome. Turk Arch Ped 2013;48:294-298.

43. Hughes IP, Choong CS, Harris M, Ambler GR, Cutfield WS, Hofman PL, Cowell CT, Werther G, Cotterill A, Davies PS; Australasian Paediatric Endocrine Group (APEG). Growth hormone treatment for Turner syndrome in Australia reveals that younger age and increased dose interact to improve response. Clin Endocrinol (Oxf) 2011;74:473480.

44. Ranke MB, Schweizer R, Martin DD, Ehehalt S, Schwarze CP, Serra F, Binder G. Analyses from a centre of short- and long-term growth in Turner's syndrome on standard growth hormone doses confirm growth prediction algorithms and show normal IGF-I levels. Horm Res Paediatr 2012;77:214-221.

45. Darendeliler F, Bas F, Berberoglu M, Öcal G, Günöz H, Darcan Ş, Bundak R, Arslanoğlu I, Yüksel B, Bideci A. Turner Sendromunda büyüme hormonu tedavi sonuçlarının değerlendirilmesi: Türkiye KIGS verileri (Pfizer Uluslararası büyüme veritabanı) veritabanı analiz sonuçları. Çocuk Dergisi 2005;5:21-26. (in Turkish)

46. Darendeliler F, Aycan Z, Cetinkaya E, Vidilisan S, Bas F, Bideci A, Demirel F, Darcan S, Buyukgebiz A, Yildiz M, Berberoglu M, Arslanoglu I, Bundak R. Effects of growth hormone on growth, insulin resistance and related hormones (ghrelin, leptin and adiponectin) in Turner syndrome. Horm Res 2007;68:1-7. Epub 2007 Jan 5

47. Yeşilkaya $E$, Bereket $A$, Darendeliler $F$, Baş F, Poyrazoğlu Ş, Küçükemre Aydın B, Darcan Ş, Dündar B, Büyükinan M, Kara C, Sarı E, Adal E, Akıncı A, Atabek ME, Demirel F, Çelik N, Özkan B, Özhan B, Orbak Z, Ersoy B, Doğan M, Ataş A, Turan S, Gökşen D, Tarım Ö, Yüksel B, Ercan O, Hatun Ş, Şimşek E, Ökten A, Abacı A, Döneray H, Özbek MN, Keskin M, Önal H, Akyürek N, Bulan K, Tepe D, Emeksiz HC, Demir K, Kızılay D, Topaloğlu AK, Eren E, Özen S, Abalı S, Akın L, Selver Eklioğlu B, Kaba S, Anık A, Baş S, Ünüvar T, Sağlam H, Bolu
S, Özgen T, Doğan D, Deniz Çakır E, Şen Y, Andıran N, Çizmecioğlu F, Evliyaoğlu O, Karagüzel G, Pirgon Ö, Çatlı G, Can HD, Gürbüz F, Binay Ç, Baş VN, Fidancı K, Polat A, Gül D, Açıkel C, Demirbilek H, Cinaz $\mathrm{P}$, Bondy C. Turner syndrome and associated problems in Turkish children: a multicenter study. J Clin Res Pediatr Endocrinol 2015;7:2736.

48. Bakker B, Frane J, Anhalt H, Lippe B, Rosenfeld RG. Height velocity targets from the national cooperative growth study for first-year growth hormone responses in short children. J Clin Endocrinol Metab 2008;93:352-357. Epub 2007 Nov 13.

49. Ranke MB, Lindberg A; KIGS International Board. Observed and predicted growth responses in prepubertal children with growth disorders: guidance of growth hormone treatment by empirical variables. J Clin Endocrinol Metab 2010;95:1229-1237. Epub 2010 Jan 22

50. Clayton PE, Cuneo RC, Juul A, Monson JP, Shalet SM, Tauber M; European Society of Paediatric Endocrinology. Consensus statement on the management of the $\mathrm{GH}$-treated adolescent in the transition to adult care. Eur J Endocrinol 2005;152:165-170.

51. Aydın BK, Aycan Z, Sıklar Z, Berberoğlu M, Ocal G, Cetinkaya S, Baş VN, Kendirci HN, Cetinkaya E, Darcan S, Gökşen D, Evliyaoğlu O, Sükür M, Baş F, Darendeliler F. Adherence to growth hormone therapy: results of a multicenter study. Endocr Pract 2014;20:46-51.

52. Kappelgaard AM, Laursen T. The benefits of growth hormone therapy in patients with Turner syndrome, Noonan syndrome and children born small for gestational age. Growth Horm IGF Res 2011;21:305313. Epub 2011 Oct 20

53. Kapoor RR, Burke SA, Sparrow SE, Hughes IA, Dunger DB, Ong KK, Acerini CL. Monitoring of concordance in growth hormone therapy. Arch Dis Child 2008;93:147-148. Epub 2007 Sep 3

54. Smith SL, HindmarSh PC, Brook CG, Compliance with growth hormone treatment-are they getting it? Arch Dis Child 1993;68:91-93.

55. Cutfield WS, Derraik JG, Gunn AJ, Reid K, Delany T, Robinson E, Hofman PL. Non-compliance with growth hormone treatment in children is common and impairs linear growth. PLoS One 2011;6:16223. 